\title{
高校運動部員の部活動ストレッサーに対する 認知的評価尺度の再構成
}

\author{
渋倉 崇行 ${ }^{1)}$ 西田 保 ${ }^{2)}$ 佐々木万丈 ${ }^{3)}$
}

Takayuki Shibukura ${ }^{1}$, Tamotsu Nishida ${ }^{2}$ and Banjou Sasaki³: Reconstruction of cognitive appraisal scale of athletic stressors for high school athletes. Japan J. Phys. Educ. Hlth. Sport Sci. 53: 147-158, June, 2008.

\begin{abstract}
The purpose of this study was to reconstruct a cognitive appraisal scale for high school athletes (Shibukura and Mori, 2004), and to examine the scale's reliability and validity. The subjects were 1370 first and second year high school athletes (903 males and 467 females). They were required to complete a questionnaire that consisted of a cognitive appraisal scale and a stress-coping scale for high school athletes. In this study we tried to devise a cognitive appraisal scale that contained "threat" and "challenge" as a primary appraisal and "controllability" as a secondary appraisal. First, as a result of factor analysis, it was revealed that a cognitive appraisal scale for high school athletes consisted of the three factors mentioned above. In this way, the cognitive appraisal scale was reconstructed. Second, the reliability of the scale was examined through the split-half method and the test-retest method. Furthermore, the content validity and the factorial validity were verified. Finally, multiple regression analyses were performed in order to examine the relationship of cognitive appraisal and coping. It became clear that a cognitive appraisal scale explained stress-coping, and the scale's predictive validity was supported. Consequently, a cognitive appraisal scale for high school athletes that contained "challenge", "threat" and "controllability" was reconstructed, and it was considered that this scale would contribute to clarification of the psychological stress process and effective stress management.
\end{abstract}

Key words : athletic club, psychological stress, factor analysis, reliability, validity キーワード：運動部, 心理的ストレス, 因子分析, 信頼性, 妥当性

\section{I 問 題}

運動部活動（以下，部活動と称す）を経験する ことは，「生きる力」（文部省, 1996）の獲得や個性 に応じた心身の発達に結びつくと考えられている (中学生・高校生のスポーツ活動に関する調查研 究協力者会議, 1997). しかし, その一方で部活動
に取り組む児童生徒の間で使いすぎ症候群，バー ンアウト, 䀧食障害, うつ状態といった心身の健 康に関わる問題が報告されている（永島, 2002). これらはスポーツに対する不適切な取り組み方が 原因となって表れた不適応症状と考えられる。こ のような中で，青木（2003）, 青木・松本（1997）, 渋倉・森（2004）は，高校運動部員（以下，部員 と称す）の部活動適応感は心理的ストレスと関係

\footnotetext{
1）県立新潟女子短期大学

干 950-8680 新潟県新潟市東区海老ヶ瀬 471

2) 名古屋大学総合保健体育科学センター

干 464-8601 愛知県名古屋市千種区不老町

3）仙台電波工業高等専門学校

干 989-3128 宮城県仙台市青葉区愛子中央 4-16-1 連絡先 渋倉崇行

1. Niigata Women's College

471 Ebigase, Higashi-ku, Niigata, Niigata 950-8680

2. Research Center of Health, Physical Fitness and Sports, Nagoya University

Furo-cho, Chikusa-ku, Nagoya, Aichi 464-8601

3. Sendai National College of Technology 4-16-1 Ayashi chuou, Aoba-ku, Sendai, Miyagi 989-3128

Corresponding authorsibukura@ece.nicol.ac.jp
} 
が深いことを指摘しており, 彼らが部活動の経験 から心身の健康に資する効果を得るためには， ス トレスマネジメントの実践が大きな意義をむつこ とが示唆される。

ストレスマネジメントは職場, 学校, 地域, 医 療, 保健領域等, 広い範囲で実践され, 個人や集 団の健康維持, 適応促進をもたらすことを目的と して行われているが (坂野, 2004; 竹中, 1997), ス卜 レスマネジメントを効果的に進めるためには彼ら のストレス反応に影響を及ぼす要因を特定し，そ の機能を詳細に検討することが必要である。この 点について, 坂野 (2004) は, ストレスマネジメ ントにおいては自分の認知の特徵を知ることや, 状況に即した柔軟な考え方ができるようになるこ とが重要であると指摘しており，ストレッサーと ストレス反応との間に介在する認知的評価が, 個 人のストレスマネジメントに扔いて重要な変数に なることを指摘している。 Lazarus and Folkman （1984）によれば，認知的評価とは刺激状況に対す る個人の主観的な評価のことであり，個人がその 状況をストレスフルと評価することによって心理 的ストレスが生じると考える. また, 認知的評価 には出来事と自分自身との利害関係を判断する一 次的評価と, 出来事をどの程度対処可能なのかを 判断する二次的評価とがあり，このうち，一次的 評価は, 恐怖や不安などのネガティブな情動に よって特徴づけられる「害一喪失」および「脅威」 の評価と, 熱意や興奮などのポジティブな情動に よって特徴づけられる「挑戦」の評価とに大きく 分類される。このような一次的評価の性質の違い が引き続くコーピング採用とストレス反応とに異 なる影響を及ぼすことが，スポーツ選手を対象と したいくつかの研究でも指摘されている (Anshel and Delany, 2001; Kim and Duda, 2003).

このような中で, 渋倉・森（2004）は部員が日 常的に経験しているストレスに注目し, その心理 的ストレス過程を検討した。 その結果, 部員の心 理的ストレス過程は「ストレッサー $\rightarrow$ 認知的評価

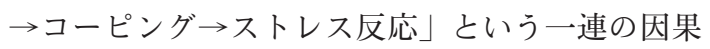
関係で説明されることが示唆され，これが Lazarus and Folkman（1984）の心理的ストレスモデルと一
致することを指摘した。しかし，このとき用いら れた認知的評価尺度は「影響性」と「コントロー ル可能性」の 2 下位尺度によるものであり, 一次 的評価を単一の因子（「影響性」）で捉えていたた めに, 出来事と自分自身とのネガティブな関係の 有無は評価されたが，そのポジティブな関係とい うところまでは評価されていない，そこで本研究 では，部員の心理的ストレスをより詳細に検討す るためには, 出来事と個人との関係がネガティブ か, あるいはポジティブかという視点を設けるこ とによって認知的評価尺度を再構成することが重 要と考えた. 今回の尺度構成が必要とされる理由 は，具体的には以下の通りである.

これまで，国内外で行われたスポーツ領域の心 理的ストレス研究は主に, 競技者のパフォーマン ス (Anshel and Kaissidis, 1997; Anshel et al., 2001), バーンアウト (Raedeke and Smith, 2001; Raedeke and Smith, 2004)，それにスポーツ傷害の発生 （Johnson et al., 2005; Rogers and Landers, 2005）との 関わりから行われてきた。しかし，近年，スポー ツ以外の領域では，心理的ストレスを個人の成長 との関わりから捉えた研究がみられるようになっ てきた (Affleck et al., 1987; McMillen et al., 1995; Updegraff et al., 2002). Park et al.（1996）は，この ような事象を「ストレスに起因する成長（stressrelated growth)」というょうに表現している。これ までのスポーツ領域における心理的ストレス研究 では，心理的ストレスを個人の生産性を低下させ たり，適応を阻害したりする要因として捉えてき たが，部活動が学校教育活動の一環として行われ る活動ということを考えると，心理的ストレスの 否定的な側面のみならず肯定的な側面にも注目す ることに大きな意味があると考えられる。このよ うなことから，部員のストレスマネジメントに対 しても「ストレス体験を通じた部員の成長」とい う要素を含めて考えることは有意義なことであり, とりわけ認知的評価については部活動ストレッ サーに直面したとしても, 積極的に問題の解決に 取り組もうとする姿勢をもてること，すなわちス トレッサーに対して挑戦の評価を行えるようにな ることは重要であると考えられる。したがって, 
部員のストレッサーに対する認知的評価尺度は, 出来事との関係をポジティブに捉える評価を新た に加えて再構成することが求められるといえる.

ところで, この尺度の使用目的は, 部員の心理 的ストレス過程の構造や因果関係を検討すること や，部員のストレスマネジメントの効果を検討す るために必要なデー夕を得ることである。そして, 再構成尺度の最大の特徵は, 一次的評価をネガ ティブとポジティブの両側面から捉えるようにす ることであるが，このことによる認知的評価尺度 の使用上のメリットとして次のことが期待される. まず，部員の心理的ストレス過程をより詳細に検 討することができるようになる，例えば，「自身の 競技力が劣っている」という事実に直面した際に, ある部員はそれを克服しようと一生懸命練習に励 むが，その一方でもうだめだと諦め, 落ち込んで しまう部員もいる。このような個人差を説明する 場合には, 部員が出来事をどのように評価したの かを判断することが重要になる。すすねち, 出来 事との関係をネガティブとポジティブの両側面か ら捉えることで, 部員がストレッサーに出会った 後のコーピングやストレス反応表出の個人差を説 明できるようになると考えられる。

また，再構成尺度を用いて部員のストレスマネ ジメントの効果を測定することにより，その指導 を効果的に行うことができるようになる，従来尺 度を利用して部員にストレスマネジメントの指導 を行うことを考えると, 個人と出来事との関係は 影響性を低く評価することに限られていた。しか し, 部活動を行っていく中では, ストレッサーと なり得る出来事であっても, 部員はその事実を受 けとめたうえで積極的に問題に関わろうとする姿 勢が必要なこともある。例えば，個人のパフォー マンスやチームワークの向上等は, 部活動で生じ る苛立ち事（競技力不足や部員間のトラブル）に 積極的に立ち向かってこそ獲得されるものである. そして，このようなストレッサーを克服する過程 で部員が成長感を味わうことも期待できる。した がって, 部員に対するストレスマネジメントの指 導は，ストレッサーに対するネガティブな評価を 低めることの他にポジティブな評価を高めるとい
うアプローチが重要となってこよう。このような ストレスマネジメントの指導を行うにあたって, 出来事との関係をネガティブとポジティブの両側 面から捉えた再構成尺度によるアセスメントが必 要と考えられる.

そこで, 本研究では渋倉・森（2004）による尺 度の「影響性」を細分化し，一次的評価のネガ ティブな側面を「脅威」の評価で，ポジティブな 側面を「挑戦」の評価で捉えることよって尺度の 再構成を行った。 Lazarus（1999），Lazarus and Folkman（1984）によれば，「脅威」と「挑戦」の 評価は対処努力を必要とする点で共通するものの, それに伴う情動は「妿威」が恐怖や不安を, そし て「挑戦」が熱意や興奮を表出するというように, それぞれが対照的な特徵をむっている。したがっ て, 心理的ストレス過程における両者の機能を比 較することにより，適応的な認知的評価の在り方 を検討することができると考えた．出来事をどの 程度対処可能なのかを判断する二次的評価は，従 来通り「コントロール可能性」の評価で捉えるこ とにした。このような 3 下位尺度による認知的評 価尺度はこれまでに作成されておらず，今回の尺 度再構成は有意義な試みといえる。また，再構成 尺度の信頼性の検討には折半法（内的整合性）と 再テスト法（再現性）を用いることにし，妥当性 については内容的妥当性, 因子的妥当性, および 予測的妥当性を検討することにした。さらに，再 構成尺度の下位尺度得点を比較することにより認 知的評価の性差を検討した。

\section{II 方法}

\section{1. 調査対象者}

$\mathrm{N}$ 県高等学校 14 校の 1,2 年生部員 1716 名のう ち, 有効回答者 1370 名（1 年生男子 484 名, 女子 247 名, 2 年生男子 419 名, 女子 220 名; 有効回収 率 $79.8 \%$ ）を分析対象とした。なお，対象運動部 は 20 種目 80 団体（個人種目 15 団体，球技系種 目 40 団体，ラケット系種目 12 団体，格闘技系種 目 8 団体，表現系種目 5 団体）であり，競技レベ ルの内訳は全国・ブロック大会が 140 名 $(10.2 \%)$, 
県大会が 721 名 $(52.6 \%)$, 市町村大会が 509 名 (37.2\%) であった.

\section{2. 調査内容}

1) 認知的評価

三浦・坂野（1996）の認知的評価尺度より下位 尺度「コントロール可能性」に含まれる項目，お よび鈴木・坂野（1998）の認知的評価尺度より 「脅威性の評価」,「コミットメント」に含まれる項 目を参考にするなどして,「妿威」,「挑戦」およ び「コントロール可能性」を表す 3 項目ずつを, 本尺度を構成する項目群とした（表 2). 本研究で は渋倉（2001）の報告に基づく5つの部活動スト レッサー（指導者, 練習時間, 競技力, 仲間, 怪 我・病気）に対する認知的評価を検討した，質問 紙の配布にあたっては，5つの部活動ストレッサー に対する回答者数が同程度になるよう配慮した。 まず，回答者は質問紙上で $5 つ の$ 部活動ストレッ サーの中から 1 つを指定され, 認知的評価の対象 を明確にしたうえで調査が行われた注 1)。そして, ストレッサーに対して認知的評価項目が示すよう な内容をどの程度感じたり考えたりするかを，「全 然そのように思わない（1点）」から「非常にその ように思う（4 点）」までの 4 段階で評定するよう 求めた。なお，ストレッサー毎の有効回答者数の 割合は，指導者ストレッサーが 21.5\%（294名), 練習時間ストレッサーが 19.6\%（269 名), 競技力 ストレッサーが 19.3\%（264名），仲間ストレッ サーが 20.7\%（283 名), 怪我・病気ストレッサー が 19.0\%（260名）であった。

2) コーピング

認知的評価尺度の予測的妥当性を検討する手続 きとして, 認知的評価とコーピングとの関連性を 検討した. 本研究では, 渋倉・森（2002）の高校 運動部員用コーピング尺度を用いた。この尺度は 「問題解決（6 項目：問題の原因を取り除くよう努 力する等) 」,「回避（6 項目：自分では手におえな いと考え諦める等) 」,「カタルシス（3 項目：誰か に話を聞いてもらい，気を静めようとする等)」, 「気晴らし（3 項目：気分を一新するようなことを する等) 」,「肯定的思考 (2 項目 : その経験は自分
のためになると考える等)」の 5 下位尺度 20 項目 で構成されている。なお，「問題解決」，「肯定的 思考」は問題焦点型の,「回避」,「カタルシス」, 「気晴らし」は情動焦点型のコーピングを表してい る（渋倉・森, 2002). 回答にあたっては, ス卜 レッサーに対してコーピング項目が示すような思 考・行動をどの程度行ったかを，「そのようにはし ない（1 点)」から「常にそのようにする（4 点)」 までの 4 段階で評定するよう求めた.

\section{3. 調查時期}

調查は 2003 年 9 月に実施された。調查時期の設 定にあたっては，部員の日常的なストレス状況を 反映させるため, 部活動への入部直後や新チーム の結成直後, あるいは試合期などの重大なストレ スイベントが起きると考えられる時期を避けるよ うにした。

\section{4. 調查方法}

調查依頼の後, 受諾済みの部顧問教諭に質問紙 を送付した。部顧問教諭から部代表生徒（キャプ テン，またはマネージャー）を介して各部員に質 問紙が配布された。宿題調査法，無記名方式で調 查を実施した。質問紙の回収は部代表生徒が回 収・厳封することとし, 記入済みの回答が顧問教 諭の目に留まらぬよう配慮した。

\section{III 結果と考察}

\section{1. 項目分析}

まず，各項目の識別力を検討するため，9項目 の度数分布を求めた（表 1)。その結果，「全然そ のように思わない（1 点)」から「非常にそのよう に思う（4 点)」までの回答に極端な偏りはみられ なかった。 つづいて，G-P分析を行った。認知的 評価尺度は「挑戦」，「脅威」，「コントロール可能 性」の 3 下位尺度を想定しているので，これらに 含まれる項目群の全体平均值をもとに分析対象者 を上位群と下位群とに分類した。各項目得点を群 間で比較（t 検定）したところ，全ての項目にお いて平均值は上位群の方が下位群よりも有意に高 
表 1 各項目に対する回答の度数分布と項目分析結果

\begin{tabular}{|c|c|c|c|c|c|c|c|c|}
\hline \multirow{2}{*}{ 項目番号 } & \multicolumn{4}{|c|}{ 回答選択肢（\%） } & \multicolumn{3}{|c|}{ 平均値 (S. D.) } & \multirow[b]{2}{*}{$t$ 值 } \\
\hline & 1 & 2 & 3 & 4 & 全体 & 上位群 & 下位群 & \\
\hline 1 & 19.56 & 28.10 & 36.28 & 16.06 & 2.49 ( . .98) & $3.21(.64)$ & $1.81(.73)$ & $37.67 * * *$ \\
\hline 2 & 12.26 & 12.55 & 26.86 & 48.32 & $3.11(1.04)$ & 3.85 (.39) & 2.31 ( .93) & $40.63 * * *$ \\
\hline 3 & 35.26 & 29.71 & 22.41 & 12.63 & $2.12(1.03)$ & $2.87(.84)$ & 1.38 (.56) & $38.60 * * *$ \\
\hline 4 & 24.82 & 30.88 & 29.64 & 14.67 & $2.34(1.01)$ & $3.09(.72)$ & 1.64 ( . .68) & $38.25^{* * *}$ \\
\hline 5 & 22.34 & 22.70 & 30.51 & 24.45 & 2.57 (1.09) & $3.32(.72)$ & $1.81(.84)$ & $35.82^{* * *}$ \\
\hline 6 & 14.82 & 13.21 & 26.79 & 45.18 & $3.02(1.08)$ & $3.82(.41)$ & $2.15(.91)$ & $44.42^{* * * *}$ \\
\hline 7 & 36.79 & 31.75 & 18.03 & 13.43 & $2.08(1.04)$ & $2.79(.91)$ & 1.36 (.56) & $35.04^{* * * *}$ \\
\hline 8 & 18.61 & 27.59 & 32.63 & 21.17 & $2.56(1.02)$ & $3.25(.70)$ & $1.92(.84)$ & $31.64 * * *$ \\
\hline 9 & 15.55 & 14.45 & 29.27 & 40.73 & $2.95(1.09)$ & $3.72(.49)$ & $2.10(.92)$ & $41.32^{* * * *}$ \\
\hline
\end{tabular}

†「挑戦」下位尺度 (項目番号 2,6,9) の全体平均值 (S. D.): 9.09 (2.91)

$* * * p<.001$

「脅威」下位尺度 (項目番号 3,5,7) の全体平均值 (S. D.): 6.78 (2.65)

「コントロール可能性」下位尺度（項目番号 1, 4,8）の全体平均值 (S. D.): 7.39 (2.52)

かった。

以上の結果から，尺度項目としてあげられた 9 項目の識別力は高いことが示された。 以下では, これら 9 項目を用いて認知的評価尺度の再構成を 行った.

\section{2. 因子分析}

尺度項目としてあげられた 9 項目に対して主因 子法, プロマックス回転による因子分析を行った （表 2)。尺度は「挑戦」, 「脅威」,「コントロール 可能性」の 3 下位尺度を想定しているので, 抽出 因子数は 3 とした。なお，因子分析は 5 つのスト レッサー毎に行われた。 その結果, いずれのスト レッサーに扔いても同様の 3 項目ずつで構成され る 3 因子が抽出され, それぞれはあらかじめ想定 した「挑戦」,「脅威」,「コントロール可能性」の 認知的評価に分類されることが示された。

以上のように,「脅威」,「挑戦」および「コン トロール可能性」を下位尺度とする認知的評価尺 度が再構成された。

\section{3. 認知的評価尺度の信頼性の検討}

1) 折半法

認知的評価尺度の各下位尺度に対応する項目群
の $\alpha$ 係数（信頼性係数）をストレッサー毎に求め た（表 2)。その結果，「挑戦」が.73から.84まで の範囲,「脅威」が.73 から.80 までの範囲,「コン トロール可能性」が.75 から.90までの範囲であっ た.

このように，信頼性係数の值は比較的高い水準 にあり，各下位尺度が一貫性の高い項目で構成さ れていることが示された。したがって，本研究に 打ける認知的評価尺度の内的整合性は高いと考え ることができる。

2）再テス卜法

認知的評価尺度を 2 週間の期間をあけて 2 回実 施した。調查対象者は高校運動部員 2 年生 203 名 （男子 92 名，女子 111 名；有効回収率 84.6\%）で あり, 調查は 2006 年 5 月に行われた。なお，調查 では回答の負担を軽減させるため，1つのストレッ サー（競技力ストレッサー）に対する認知的評価 について回答を求めた。 1 回目調査と 2 回目調査 に扔ける下位尺度毎の相関係数は，「挑戦」が.85, 「妿威」が.81,「コントロール可能性」が.76とい う結果であった。

このように，信頼性係数の值は比較的高い水準 にあり，再テスト法により各下位尺度の再現性が 示された。 したがって, 本研究における認知的評 


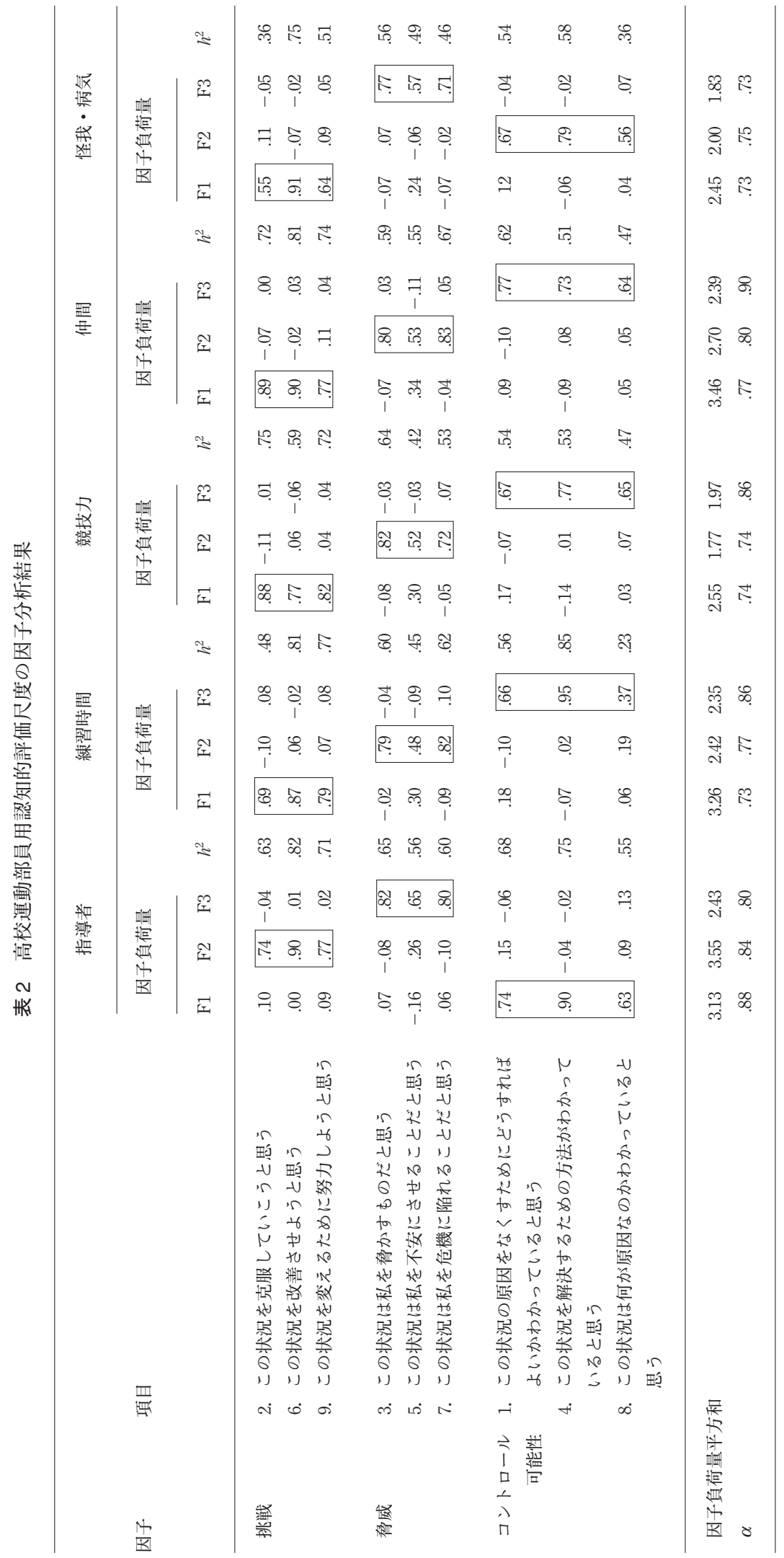


価尺度の再現性は高いと考えることができる。

\section{4. 認知的評価尺度の妥当性の検討}

1）内容的妥当性

本研究では, 認知的評価尺度を「挑戦」,「脅 威」抢よび「コントロール可能性」の各評価で捉 えることで尺度構成を試みている，本尺度を構成 する項目群の選択にあたっては, 認知的評価尺度 として高い妥当性が認められる三浦・坂野 (1996), および鈴木・坂野（1998）により作成された尺度 項目を参考にするなどして 9 項目が準備された. 因子分析の結果, 尺度を構成する項目は準備され た 9 項目であることから, 本研究における認知的 評価尺度の内容的妥当性は高いと考えることがで きる.

2）因子的妥当性

認知的評価尺度を再構成するにあたって因子分 析を行った結果, 「挑戦」,「脅威」および「コン トロール可能性」の 3 つ因子が抽出されている. これらはいずれも既に開発された認知的評価を測 定する尺度に含まれる下位尺度と対応していた。 すなわち，本尺度における「挑戦」は鈴木・坂野 （1998）の「コミットメント」と,「脅威」は鈴 木・坂野 (1998) の「脅威性の評価」と, そして 「コントロール可能性」は三浦・坂野（1996）の 「コントロール可能性」とそれぞれ対応する因子で あった。さらに, 本研究に打ける抽出因子は Lazarus and Folkman（1984）が提唱する認知的評 価の中心的構成概念であり，「挑戦」と「脅威」 は一次的評価に,「コントロール可能性」は二次 的評価に対応している.

以上のことから, 本研究に扔ける認知的評価尺 度の因子的妥当性は高いと考えられる。

3）予測的妥当性

Lazarus and Folkman（1984）の心理的ストレス 理論によれば，認知的評価はそれに引き続いて起 こるコーピング採用を説明すると指摘されている. そこで, 認知的評価尺度の予測的妥当性を検討す る外的基準として, 部活動ストレッサーに対する コーピングを取りあげ，両変数間の関連性を分析 した。 また,これまでの研究から, 挑戦的でコン
トロールできると評価された状況ではその状況に 関わるストレスフルな出来事をなくす活動に従事 しやすいことや，脅威的でコントロール不可能と 評価された状況ではそれに伴うネガティブな情動 を低減させるよう行動しやすいことが指摘されて いる (Anshel and Delany, 2001; Anshel et al., 2001; Anshel and Kaissidis, 1997; 加藤, 2001; 三浦 -上里, 1999; 嶋田, 1998; 嶋田ほか, 1996; 鈴木・坂野, 1998). これらの報告をふまえると, 認知的評価尺度の下 位尺度「挑戦」と「コントロール可能性」は問題 焦点型コーピングとは正の関連性を, 情動焦点型 コーピングとは負の関連性を示すことが予想され る。また, 認知的評価尺度の「脅威」は問題焦点 型コーピングとは負の関連性を, 情動焦点型コー ピングとは正の関連性を示すことが予想される。

本研究では, 認知的評価 3 下位尺度を説明変 数, コーピング 5 下位尺度を基準変数とした重回 帰分析（強制投入法）を行い，認知的評価尺度の 予測的妥当性を検討した（表 3)。なお，分析は 5 つのストレッサー毎に行われた。

分析の結果，重相関係数の值は，怪我・病気又 トレッサーにおける「気晴らし」を除く全ての組 み合わせで有意であった。 また，標準偏回帰係数 は,「挑戦」が全てのストレッサーの「問題解決」 との間で，練習時間以外のストレッサーにおける 「肯定的思考」との間でそれぞれ有意な正の值を示 した。 また，指導者，競技力，仲間の各ストレッ サーにおける「回避」との間で, 競技力ストレッ サーに抽け「カタルシス」,「気晴らし」との間 でそれぞれ有意な負の值を示した。一方，練習時 間ストレッサーにおける「カタルシス」,「気晴ら し」との間で，仲間ストレッサーに打ける「カタ ルシス」との間でそれぞれ有意な正の值を示した. 次に,「脅威」は, 怪我・病気以外のストレッサー の「回避」,「カタルシス」,「気晴らし」との間で, 怪我・病気ストレッサーの「回避」,「カタルシス」 との間でそれぞれ有意な正の值を示した。 さらに, 「コントロール可能性」は, 怪我・病気以外のス トレッサーの「問題解決」，「肯定的思考」との間 で, 怪我・病気ストレッサーの「問題解決」との 間でそれぞれ有意な正の值を示した。また，怪 
表 3 認知的評価を説明変数, コーピングを基準変数とした重回帰分析結果

\begin{tabular}{|c|c|c|c|c|c|c|}
\hline \multirow{2}{*}{ ストレッサー } & \multirow{2}{*}{ 認知的評価 } & \multicolumn{5}{|c|}{ コーピング } \\
\hline & & 問題解決 & 回避 & カタルシス & 気晴らし & 肯定的思考 \\
\hline \multirow[t]{4}{*}{ 指導者 } & 挑戦 & $.32^{* * * *}$ & $-.19 *$ & .04 & .13 & $.27^{* * * *}$ \\
\hline & 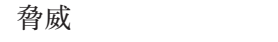 & .10 & $.30 * * *$ & $.21 * * *$ & $.27 * * *$ & .02 \\
\hline & コントロール可能性 & $.20 * *$ & -.05 & .07 & .02 & $.14^{*}$ \\
\hline & $R$ & $.52^{* * * *}$ & $.30 * * *$ & $.26^{* * * *}$ & $.36^{* * * *}$ & $.39 * * *$ \\
\hline \multirow[t]{4}{*}{ 練習時間 } & 挑戦 & $.39 * * *$ & -.13 & $.19 *$ & $.16^{*}$ & .06 \\
\hline & 脅威 & .07 & $.40 * * *$ & $.23 * * *$ & $.14^{*}$ & -.05 \\
\hline & コントロール可能性 & $.20^{* *}$ & -.06 & .04 & $.15^{*}$ & $.22^{* *}$ \\
\hline & $R$ & $.55^{* * *}$ & $.35^{* * * *}$ & $.38^{* * * *}$ & $.35^{* * * *}$ & $.24^{* *}$ \\
\hline \multirow[t]{4}{*}{ 競技力 } & 挑戦 & $.36^{* * *}$ & $-.44 * * *$ & $-.14^{*}$ & $-.21^{* *}$ & $.15^{*}$ \\
\hline & 脅威 & .09 & $.19 * *$ & $.27 * * *$ & $.20 * *$ & .03 \\
\hline & コントロール可能性 & $.19 * *$ & -.07 & .04 & -.03 & $.22^{* * *}$ \\
\hline & $R$ & $.50^{* * * *}$ & $.46^{* * * *}$ & $.28^{* * *}$ & $.25^{* *}$ & $.32^{* * *}$ \\
\hline \multirow[t]{4}{*}{ 仲間 } & 挑戦 & $.47 * * *$ & $-.25^{* *}$ & $.17^{*}$ & .05 & $.23 * *$ \\
\hline & 脅威 & .11 & $.14^{*}$ & $.16^{*}$ & $.23 * * *$ & .09 \\
\hline & コントロール可能性 & $.14^{* *}$ & .12 & $.20^{* *}$ & .09 & $.19^{* *}$ \\
\hline & $R$ & $.62 * * *$ & $.20 *$ & $.42^{* * * *}$ & $.30 * * *$ & $.41^{* * * *}$ \\
\hline \multirow[t]{4}{*}{ 怪我・病気 } & 挑戦 & $.47^{* * * *}$ & -.14 & .05 & .14 & $.25^{* * * *}$ \\
\hline & 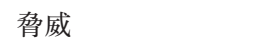 & .04 & $.16^{*}$ & $.21^{* *}$ & .04 & .02 \\
\hline & コントロール可能性 & $.16^{* * *}$ & $-.15^{*}$ & -.05 & -.02 & .08 \\
\hline & $R$ & $.58 * * *$ & $.26^{* *}$ & $.23^{* *}$ & .15 & $.31^{* * * *}$ \\
\hline
\end{tabular}

我・病気ストレッサーの「回避」との間で有意な 負の值を示した。一方, 練習時間ストレッサーに おける「気晴らし」との間で, 仲間ストレッサー における「カタルシス」との間でそれぞれ有意な 正の值を示した.

以上をまとめると，全般的に「挑戦」と「コン トロール可能性」の評価は問題焦点型コーピング (「問題解決」, 「肯定的思考」) と正の関連性が, 「脅威」の評価は情動焦点型コーピング（「回避」, 「カタルシス」，「気晴らし」）と正の関連性がある
ことがそれぞれ認められた。 また，「挑戦」と「コ ントロール可能性」の評価は情動焦点型コーピン グと負の関連性があることが認められた。これら の結果は先行研究を支持しており, 予想とほぼ一 致した。したがって, 本研究における認知的評価 尺度の予測的妥当性は高いと考えることができる.

\section{5. 認知的評価尺度の性差}

認知的評価の性差を検討するため, 認知的評価 3 下位尺度それぞれについて $t$ 検定を行った（表 
4)。なお，分析は 5 つのストレッサー毎に行われ た。その結果, 練習時間ストレッサーに打りる 「挑戦」 $\left(t_{267}=4.14, p<.001\right)$, および仲間ストレッ サーにおける「挑戦」（ $t_{281}=3.68, p<.001 ）$ と「脅 威」 $\left(t_{281}=3.19, p<.01\right)$ に抢いてのみ有意差が認め られ，いずれも女子の方が男子よりも高かった。

以上の結果から，女子は男子よりも，練習時間 ストレッサーを克服すべき挑戦の対象として評価 する傾向が強いことが，仲間ストレッサーに対し ては挑戦の対象として評価する傾向とともに，そ れを自分にとって艿威であると評価する傾向も強 いことが示された。 また，その他のストレッサー に対する認知的評価に性差はないことが示された。 本研究では, 一部の部活動ストレッサーにおいて 認知的評価の性差が示唆されたが, 今後, 尺度の 標準化を行う場合にはそのことを考慮し, 男女別 に検討することが必要といえる.

\section{IV まとめと今後の課題}

本研究の目的は, 渋倉・森（2004）の高校運動 部員用認知的評価尺度を再構成し，その信頼性と 妥当性を検討することであった。分析の結果は以 下の通りである。

1）再構成のため収集された 9 項目は高い識別力 があり, さらに, 因子分析の結果からは, 従来の 「影響性」のポジティブな側面としては「挑戦」 を，また，ネガティブな側面としては「脅威」を 構成概念として持ち，「コントロール可能性」とあ わせて 3 下位尺度からなる認知的評価尺度を再構 成することができた。

2）認知的評価尺度の各下位尺度に対応する項 目群の $\alpha$ 係数は比較的高い水準にあり，その内的 整合性は高いことが示された。また，再テスト法 では信頼性係数の值が比較的高い水準にあり, 認 知的評価尺度の再現性の高さが示唆された。

3）本研究に用いられた項目は，認知的評価尺 度として高い妥当性が認められる尺度項目を参考 にするなどして準備された。 また，因子分析の結 果として抽出された 3 因子は既存の認知的評価を 測定する下位尺度と対応していた。これらのこと

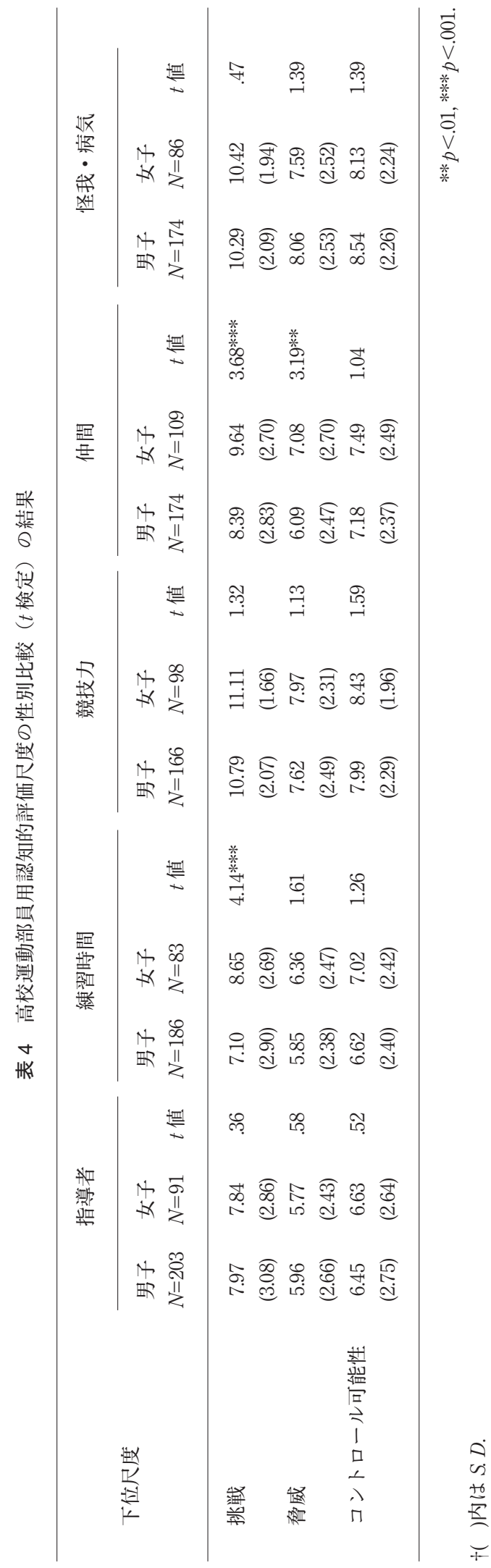


から, 認知的評価尺度の内容的妥当性, 因子的妥 当性は高いと考えられた。

4）重回帰分析の結果，本尺度によって表され る認知的評価はそれに引き続くコーピング採用を 説明しており，この結果は Lazarus and Folkman （1984）の心理的ストレス理論における両変数の密 接な関係を表していた。このことから, 認知的評 価尺度の予測的妥当性は高いと考えられた。

ところで, 再構成尺度に抢ける最大の特徵は, 一次的評価をネガティブとポジティブの両側面か ら捉えることである。したがって，本尺度を用い ることで, 部員のコーピングやストレス反応表出 の個人差を認知的評価の側面から検討することが 可能になったといえる。また，これまで部活動に おけるストレス体験は部員の不適応を助長する要 因としての見方が強かったが，近年は部員が成長 するための機会としてストレス体験を捉えていく ことの重要性も指摘されている（渋倉ほか, 2006）. したがって, 今後は部員の適応状態に応じた柔軟 なストレスマネジメントの指導が求められるよう になるであろう。この点において，ストレッサー に対するネガティブな評価とポジティブな評価の 両側面から介入の視点を提供できる本尺度の有用 性は高いといえる。

本尺度の具体的な使用についてであるが，今後， 部員用のストレスマネジメントプログラムを実施 することが想定される．プログラムの実施前に本 尺度を使用することによって，どの部員に対して どのような働きかけを行う必要があるのかを特定 することが可能となる，例えば，ストレッサーに 対する「脅威」の評価が高い部員に対しては，そ の刺激の影響を論理的に分析させることにより， ストレッサーを「たいしたことではない」という ように認識できることが重要となる。また，「挑 戦」の評価が低い部員に対しては, 部活動スト レッサーに積極的に対応していくことで，自分に どのようなメリットがあるのかを検討させること が重要となる。 さらに，「コントロール可能性」の 評価が低い部員に対しては, 過去に類似の状況を 克服してきた体験を想起させたり，周囲の部員も 同様のストレッサーを克服していることを認識さ
せたりすることが重要となる。これらの取り組み によって，ストレッサーに対する部員の「脅威」 の評価を低め,「挑戦」と「コントロール可能性」 の評価を高めることができるであろう。また，プ ログラムの実施前後の下位尺度得点を比較するこ とによって，介入の効果を判断することも可能と なる。

最後に, 本研究では部員の認知的評価の特徵を 性差の観点から検討を行ったが，部員が直面する ストレッサーは競技生活やスポーツ集団といった 部活動の特徵が色濃く反映することを考えると， 単純に性差を検討するよりも，活動時期や対象者 の特性に応じた比較が求められると思われる。し たがって，今後は部員の成熟段階（入部初期, 中 期，後期）や重大なイベント（試合期，新チーム 編成期等）に注目した継時的変化を検討すること， そして集団内に打りる地位（レギュラー，非レ ギュラー）や競技レベルなど様々な属性の対象者 を比較することにより, 部員のストレスマネジメ ントを有効に進められる知見の生成を課題とした い.

\section{注}

注 1）回答者が質問紙上で 1 つのストレッサーを指定さ れる際には，当該ストレッサーを表す下位尺度項目 も同時に提示することにより，その状況をイメージ しやすいようにした，ストレッサー下位尺度の項目 例を以下に示す，指導者：指導者の考えが自分の考 えとあわないこと．指導者が理解を示してくれない こと. 練習時間 : 部活動に多くの時間がとられ好き なことができないこと，休日が少ないこと．競技 力：自分の競技能力が低いと感じること. 努力して 練習しているのに上達しないと感じること. 仲間： 他の部員の考え方と自分の考え方が合わないこと. 部内にまとまりがないこと。怪我・病気：怪我や病 気で練習ができないこと，怪我や病気で試合にでら れないこと.

\section{文献}

Affleck, G., Tennen, H., Crrog, S., and Levine, S. (1987) Causal 
attribution, perceived benefits, and morbidity after a heart attack: An 8-year study. Journal of Consulting and Clinical Psychology, 55: 29-35.

Anshel, M. H. and Delany, J. (2001) Sources of acute stress, cognitive appraisals, and coping strategies of male and female child athletes. Journal of Sport Behavior, 24: 329-353.

Anshel, M. H., Jamieson, J., and Raviv, S. (2001) Cognitive appraisal and coping strategies following acute stress among skilled competitive male and female athletes. Journal of Sport Behavior, 24: 128-143.

Anshel, M. H., and Kaissidis, A. N. (1997) Coping styles and situational appraisals as predictors of coping strategies following stressful events in sport as a function of gender and skill level. British Journal of Psychology, 88: 263-276.

Anshel, M. H. and Wells, B. (2000) Personal and situational variables that describe coping with acute stress in competitive sport. The Journal of Social Psychology, 140: 434-450.

青木邦男（2003）高校運動部員のスポーツ観とそれに関 連する要因. 体育学研究, 48: 207-223.

青木邦男・松本耕二（1997）高校運動部員の部活動適応 感に関連する心理社会的要因. 体育学研究, 42: 215232.

中学生・高校生のスポーツ活動に関する調査研究協力者 会議（1997）運動部活動の在り方に関する調査研究報 告. 文部省.

Johnson, U., Ekengren, J., and Andersen, M. B. (2005) Injury prevention in Sweden: Helping soccer players at risk. Journal of Sport and Exercise Psychology, 27: 32-38.

加藤 司 (2001) 対人ストレス過程の検証. 教育心理学 研究, 49: 295-304.

Kim, M. S. and Duda, J. L. (2003) The coping process: Cognitive appraisals of stress, coping strategies, and coping effectiveness. The Sport Psychologist, 17: 406-425.

Lazarus, R. S. and Folkman, S. (1984) Stress, appraisal, and coping. Springer Publishing Company: New York.

Lazarus, R. S. (1999) Stress and emotion. Springer Publishing Company: New York.

McMillen, C., Zuravin, S., and Rideout, G. (1995) Perceived benefit from child sexual abuse. Journal of Consulting and Clinical Psychology, 63: 1037-1043.

三浦正江・上里一郎（1999）中学生の学業における心理 的ストレスー高校受験期に実施した調查研究から一. ヒューマンサイエンスリサーチ，8: 87-102.

三浦正江・坂野雄二（1996）中学生における心理的ス卜
レスの継時的変化. 教育心理学研究, 44: 368-378. 文部省（1996）21 世紀を展望した我が国の教育の在り方 について：第 15 期中央教育審議会第一次答申. 文部 時報, 1437: 1-166.

永島正紀（2002） スポーツ少年のメンタルサポート：精 神科医のカウンセリングノートから．講談社：東京.

Park, C. L., Cohen, L. H., and Murch, R. L. (1996) Assessment and prediction of stress-related growth. Journal of Personality, 64: 71-105.

Raedeke, T. D., and Smith, A. L. (2001) Development and preliminary validation of an athlete burnout measure. Journal of Sport and Exercise Psychology, 23: 281-306.

Raedeke, T. D., and Smith, A. L. (2004) Coping resources and athlete burnout: A examination of stress mediated and moderation hypotheses. Journal of Sport and Exercise Psychology, 26: 525-541.

Rogers, T. J., and Landers, D. M. (2005) Mediating effects of peripheral vision in the life event stress/athletic injury relationship. Journal of Sport and Exercise Psychology, 27: 271-288.

坂野雄二監（2004）学校, 職場, 地域におけるストレス マネジメント実践マニュアル，北大路書房：京都.

渋倉崇行（2001）高校運動部員の部活動ストレッサーと ストレス反応との関連. 新潟工科大学研究紀要, 6 : 137-146.

渋倉崇行・森 恭（2002）高校運動部員の部活動ス卜 レッサーに対するコーピング採用とストレス反応との 関連. スポーツ心理学研究, 29(2): 19-30.

渋倉崇行・森 恭 (2004) 高校運動部員の心理的ス卜 レス過程に関する検討. 体育学研究，49: 535-545.

渋倉崇行・西田 保・佐々木万丈（2007）高校運動部員 における部活動ストレス体験の意味：部活動に適応的 な部員の検討. 総合保健体育科学, 30:47-56.

嶋田洋徳（1998）小中学生の心理的ストレスと学校不適 応に関する研究. 風間書房 : 東京.

嶋田洋徳・三浦正江・坂野雄二・上里一郎（1996）小学 生の学校ストレッサーに対する認知的評価がコーピン グとストレス反応に及ぼす影響. カウンセリング研究, 29: 89-96.

鈴木伸一 - 坂野雄二（1998）認知的評価測定尺度 （CARS）作成の試み. ヒューマンサイエンスリサーチ, 7: 113-124.

竹中晃二編（1997）子どものためのストレス・マネジメ ント教育：対症療法から予防措置への転換. 北大路書 
房: 京都.

Updegraff, J. A., Taylor, S. E., Kemeny, M. E., and Wyatt, G. E. (2002) Positive and negative effects of HIV infection in women with low socioeconomic resources. Personality and
Social Psychology Bulletin, 28: 382-394.

$\left(\begin{array}{l}\text { 平成 } 19 \text { 年 } 3 \text { 月 } 16 \text { 日受付 } \\ \text { 平成 } 20 \text { 年 } 2 \text { 月 } 16 \text { 日受理 }\end{array}\right)$ 